\title{
Kepemimpinan Perempuan di Masa Krisis: Studi Kasus Bupati Serang Dalam Penanganan Covid-19
}

\author{
Bayu Nurrohman ${ }^{1}$ \\ Department of Government, Universitas Sultan Ageng \\ Tirtayasa, Indonesia \\ bayu.nurrohman@untirta.ac.id \\ Gilang Ramadhan ${ }^{2}$ \\ Department of Government, Universitas Sultan Ageng \\ Tirtayasa, Indonesia \\ gilang.ramadhan@untirta.ac.id
}

E-ISSN (2721-0642)
Recieved:
October 182020
Revised:
December 142020
Accepted:
December 212020
Doi Number
https://doi.org/10.37950/ijd.v2i3.67

\section{Abstract}

This research tries to see how the female leader in handling Covid-19 in this case is the Regent of Serang, Hj. Ratu Tatu Chasanah in handling the Covid-19 crisis in Serang Regency. This research is important to do because in the midst of the increasing issue of gender pengarustamaan and women's leadership, researchers want to study the quality of elected female regional heads when facing a crisis that occurs in their region. This research offers another approach in research because it tries to see the quality of women regional heads in facing crises, while other research on women leaders tends to portray in quantity how women are represented in both the executive and legislative realms. While the focus of this research is in Serang Regency, Banten Province, because seeing Serang Regency is one of the areas led by women. Furthermore, Serang Regency is also the location where the new Untirta Campus is located. Researchers want to see further how the handling of Covid-19 in Serang Regency is one of the contributions to the scientific development and society of Serang Regency, especially as the object of receiving public policies from the local government.

Keywords: female leadership, Covid-19, serang regency

\begin{abstract}
Abstrak
Riset ini mencoba melihat bagaimana pemimpin perempuan dalam penanganan Covid19 dalam hal ini adalah Bupati Serang, Hj. Ratu Tatu Chasanah dalam penanganan krisis Covid-19 di Kabupaten Serang. Riset ini menjadi penting dilakukan karena ditengah isu pengarustamaan gender dan kepemimpinan perempuan yang semakin kencang, peneliti ingin mengkaji kualitas kepala daerah perempuan yang terpilih ketika menghadapi
\end{abstract}


krisis yang terjadi di daerahnya. Riset ini menawarkan pendekatan lain dalam penelitian karena mencoba melihat kualitas kepala daerah perempuan dalam menghadapi krisis, sementara penelitian lainnya mengenai pemimpin perempuan lebih cenerung memotret secara kuantitas bagaimana keterwakilan perempuan baik dalam ranah eksekutif maupun legislative.Sementara focus dari riset ini adalah di Kabupaten Serang Provinsi Banten, Karena melihat Kabupaten Serang adalah salah satu daerah yanag dipimpin oleh perempuan. Lebih lanjut Kabupaten Serang juga merupakan lokasi dimana Kampus Untirta yang baru berada. Peneliti ingin melihat lebih jauh bagaimana penanganan Covid-19 di Kabupaten Serang sebagai salah satu sumbangsih bagi pengembangan keilmuan dan masyarakat Kabupaten Serang khususnya sebagai objek penerima kebijakan public dari pemerintah daerah.

Kata Kunci: Kepemimpinan Perempuan, Covid-19, Kabupaten Serang

\section{Pendahuluan}

Menyebarnya Covid-19 yang begitu cepat membuat seluruh negara merespon dengan bergerak sedemikian rupa untuk dapat menangani krisis ini. Indonesia adalah salah satu negara yang tak lepas dari masalah pandemic ini. Data terakhir per tanggal 26 April 2020 menunjukan Kasus yang terkonfirmasi positif mencapai 8.607,sembuh 1.042, dan meninggal 720. (Sumber https://www.covid19.go.id/)

Tingginya angka yang terkonfirmasi positif Covid-19 menggambarkan betapa berbahayanya pandemic ini. Penyebaran virus ini membuat negara mengalami kondisi krisis, bahkan Indonesia telah menyatakan kejadian Luar Biasa atas kejadian ini. Di level pemerintah daerah, berbagai kebijakan diselaraskan dengan pemerintah pusat guna menanggulangi penyebaran Covid-19. Namun implementasi dari kebijakan yang telah diambil dalam penanggulangan Covid-19 di daerah dilaksanakan secara beragam, yang menunjukan bahwa kapasitas ketiap kepala daerah sangat menentukan bagaimana daerah tersebut menghadapi krisis pandemic ini di daerahnya masing-masing.

Provinsi Banten merupakan salah satu wilayah yang memiliki kasus terkonfirmasi ositif yang tinggi jika dibandingkan dengan seluruh Provinsi yang ada di Indonesia. Tingginya kasus positif di Banten salah satunya karena lokasinya yang berbatasan dengan zona paling merah yaitu DKI Jakarta.

Tingginya angka kasus di Provinsi Banten merupakan akumulasi dari seluruh Kabupaten dan Kota yang ada di Provinsi Banten. Salah satu daerah yang juga terdapat kasus positif adalah Kabupaten Serang. Meskipun bukan daerah yang memiliki kasus tertinggi di Banten, namun peta sebaran kasus Covid-19 di Kabupaten Serang patut mendapat perhatian.

Dari data di atas menunjukan bahwa Kabupaten Serang juga tidak luput dari krisis yang diakbiatkan oleh Pandemi ini. Sama halnya dengan daerah lain, penanganan Covid-19 ini memerlukan peran dan keterampilan seorang pemimpin. Peran pemimpin sangat penting dalam menangani permasalahan pandemik ini sejalan dengan Surat Edaran Mendagri No.440/2622/SJ Tanggal 29 Maret 2020 yang memberikan mandat kepada kepala daerah untuk menjadi Gugus Tugas di daerah. Krisis ini seakan menjadi ujian dan ukuran bagaimana seorang pemimpin mampu menyelesaikan permsalahan pada saat krisis atau tidak. 
Pada level nasional, gugus tugas percepatan penanggulangan covid 19 hanya didominasi oleh tokoh laki-laki, hanya ada satu perempuan yang menjadi bagian dari gugus tugas yakni menteri ekonomi yang menduduki posisi sebagai pengarah, namun belakangan diberitakankan Sri Mulyani menghilang dari gugus tugas ini. Lalu, jika merujuk kepada ketua gugus tugas di level daerah maka representasi perempuan dalam gugus tugas ini adalah 87 dari 1096 kepala daerah atau sekitar 8\%. Data ini mengacu kepada data kepala daerah perempuan terpilih hasil pemilu 2015, 2017 dan 2018 (Kementerian Pemberdayaan Perempuan dan Perlindungan Anak, 2018). Angka 8\% adalah sangat kecil jika merujuk pada angka 30\% kebijakan afirmasi yang diamanatkan oleh Undang-Undang Pemilu.

Kabupaten Serang adalah salah satu daerah dari 3 daerah lainnya di Banten yang memiliki kepala daerah perempuan. Menariknya melihat penanganan Covid-19 di Kabupaten Serang ini salah satunya adalah karena Kabupaten Serang dipimpin oleh seorang kepala daerah perempuan (Wieringa, 2010). Jika melihat penanganan pemimpin perempuan sebagai kepala negara, beberapa tulisan mengarah kepada penanganan yang lebih baik dibandingkan dengan kepala negara laki-laki seperti misalnya penanganan yang dilakukan oleh Jacinda Arnern di Selandia Baru, sampai Tsai Ing Wen di Taiwan.

Dari berbagai macam permasalahan yang telah dijelaskan diatas, riset ini mencoba melihat bagaimana pemimpin perempuan dalam penanganan Covid-19 dalam hal ini adalah Bupati Serang, Hj. Ratu Tatu Chasanah dalam penanganan krisis Covid-19 di Kabupaten Serang. Riset ini menjadi penting dilakukan karena ditengah isu pengarustamaan gender dan kepemimpinan perempuan yang semakin kencang, peneliti ingin mengkaji kualitas kepala daerah perempuan yang terpilih ketika menghadapi krisis yang terjadi di daerahnya. Riset ini menawarkan pendekatan lain dalampenelitian karena mencoba melihat kualitas kepala daerah perempuan dalam menghadapi krisis, sementara penelitian lainnya mengenai pemimpin perempuan lebih cenerung memotret secara kuantitas bagaimana keterwakilan perempuan baik dalam ranah eksekutif maupun legislatif.

Sementara focus dari riset ini adalah di Kabupaten Serang Provinsi Banten, Karena melihat Kabupaten Serang adalah salah satu daerah yanag dipimpin oleh perempuan. Lebih lanjut Kabupaten Serang juga merupakan lokasi dimana Kampus Untirta yang baru berada. Peneliti ingin melihat lebih jauh bagaimana penanganan Covid-19 di Kabupaten Serang sebagai salah satu sumbangsih bagi pengembangan keilmuan dan masyarakat Kabupaten Serang khususnya sebagai objek penerima kebijakan public dari pemerintah daerah.

\section{Kerangka Teori}

Kepemimpinan secara harfiah berasal dari kata pimpin. Kata pimpin mengandung pengertian mengarahkan, membina atau mengatur, menuntun dan juga menunjukkan ataupun mempengaruhi. Pemimpin mempunyai tanggung jawab baik secara fisik maupun spiritual terhadap keberhasilan aktivitas kerja dari yang dipimpin, sehingga menjadi pemimpin itu tidak mudah dan tidak akan setiap orang mempunyai kesamaan di dalam menjalankan ke-pemimpinannya. Miftah Thoha (2010: 9) kepemimpinan adalah kegiatan untuk memengaruhi perilaku orang lain, atau seni memengaruhi perilaku manusia baik perorangan maupun kelompok.

Kepemimpinan merupakan salah satu faktor yang sangat penting dalam suatu organisasi karena sebagian besar keberhasilan dan kegagalan suatu organisasi 
ditentukan oleh kepemimpinan dalam organisasi tersebut. Menurut C. Turney (1992) mandefinisikan kepemimpinan sebagai suatu group proses yang dilakukan oleh seseorang dalam mengelola dan menginspirasikan sejumlah pekerjaan untuk mencapai tujuan organisasi melalui aplikasi teknik- teknik manajemen. George R. Terry (Miftah Thoha, 2010: 5) mengartikan bahwa Kepemimpinan adalah aktivitas untuk mempengaruhi orang-orang supaya diarahkan mencapai tujuan organisasi. Kepemimpinan meliputi proses mempengaruhi dalam menentukan tujuan organisasi, memotivasi perilaku pengikut untuk mencapai tujuan, mempengaruhi untuk memperbaiki kelompok dan budayanya.

Menurut Sudarwan Danim (2004: 56) kepemimpinan adalah setiap perbuatan yang dilakukan oleh individu atau kelompok untuk mengkoordinasi dan memberi arah kepada individu atau kelompok yang tergabung di dalam wadah tertentu untuk mencapai tujuan yang telah ditetapkan sebelumnya.

Kepemimpinan perempuan dalam jabatan publik dapat di artikan sebagai kegiatan mempengaruhi perilaku orang lain yang di lakukan oleh perempuan dalam menjalankan tugas pokok, fungsi, keahlian serta keterampilan agar tercapainya suatu tujuan. Berikut lima ciri yang dimiliki pemimpin perempuan (Fitriani, 2015) : Pertama, kemampuan untuk membujuk, wanita pemimpin umumnya lebih persuasif bila dibandingkan dengan pria, la cenderung lebih berambisi dibandingkan pria. keberhasilannya dalam membujuk orang lain untuk berkata "ya" akan meningkatkan egonya dan memberinya kepuasan. Meskipun demikian, saat memaksakan kehendaknya, sisi sosial, feminin, dan sifat empatinya tidak akan hilang. Kedua, membuktikan kritikan yang salah, mereka "belum bermuka tebal", wanita pemimpin memiliki tingkat kekuatan ego yang lebih rendah dibandingkan pria, artinya mereka masih bisa merasakan rasa sakit akibat penolakan dan kritik. Namun, tingkat keberanian, empat, keluwesan, dan keramahan yang tinggi membuat mereka cepat pulih, belajar dari kesalahan, dan bergerak maju dengan sikap positif "akan saya buktikan". Ketiga, semangat kerja tim, wanita pemimpin yang hebat cenderung menerapkan gaya kepemimpinan secara komprehensif saat harus menyelesaikan masalah dan membuat keputusan. Mereka juga lebih fleksibel, penuh pertimbangan, dan membantu stafnya. Keempat, sang pemimpin, wanita pemimpin yang hebat umumnya memiliki kharisma yang kuat, begitu juga pria. Mereka persuasif, percaya diri, serta berkemauan kuat untuk menyelesaikan tugas dan energik. Kelima, berani mengambil risiko, tidak lagi berada di wilayah yang aman, wanita pemimpin pada dasarnya berani melanggar aturan dan mengambil risiko, sama seperti pria sekaligus memberi perhatian yang sama pada detail. Mereka berspekulasi di luar batas-batas perusahaan, dan tidak sepenuhnya menerima aturan struktural yang ada (peraturan perusahaan).

Fearn-Banks (1996:1) mendefinisikan krisis sebagai "a major occurrence with a potentially negative outcome affecting an organization, company or industry, as well as its publics, products, services or good name". Biasanya sebuah krisis mengganggu transaksi normal dan kadang mengancam kelangsungan hidup atau keberadaan organisasi. Krisis pada dasarnya adalah sebuah situasi yang tidak terduga, artinya organisasi umumnya tidak dapat menduga bahwa akan muncul krisis yang dapat mengancam keberadaanya (Fadhilah, 2011). Sebagai ancaman ia harus ditangani secara cepat agar organisasi dapat berjalan normal kembali setelah itu. Krisis membawa keterkejutan dan sekaligus mengancam nilai-nilai penting organisasi serta hanya ada waktu yang singkat untuk mengambil keputusan. Shrivastava dan Mitroff (1987) mendefiniskan krisis perusahan sebagai "Events that threaten their most important goals of survival and profitability". 
"Krisis juga dianggap sebagai "turning point in history life", yaitu suatu titik balik dalam kehidupan yang dampaknya memberikan pengaruh signifikan, kearah negatif maupun positif, tergantung reaksi yang diperlihatkan oleh individu, kelompok masyarakat, atau suatu bangsa. Krisis dapat terjadi secara alamiah, tidak terprediksi dan tidak selalu merupakan hal buruk. Hasil riset menunjukkan hasil bahwa ternyata outcome dari situasi krisis memberikan skor yang berimbang atau sama antara yang positif (seperti yang diharapkan) dan yang negatif (yang tidak diharapkan). Dalam menghadapi krisis, optimisme untuk menyusun langkah-langkah agar dapat keluar dari krisis merupakan modal utama. Pemberitaan media massa yang menggiring kearah sisi negatif harus diseimbangkan. Hal penting yang dapat dilakukan adalah mempengaruhi pola pikir masyarakat bahwa krisis tidak selalu memiliki sisi negatif, tetapi juga sisi positif.

Tiga tahapan penanganan krisis menurut Coombs (2007: 18-20) sebagai berikut. Pertama, tahap precrisis. Tahap pra krisis melibatkan tiga sub tahap, yaitu : (a) Signal detection, mengidentifikasi sumber-sumber yang menjadi tanda-tanda peringatan, mengumpulkan informasi yang berhubungan dengan mereka, dan menganalisis informasi. (b) Prevention, setelah potensi resiko terdeteksi, tindakan harus diambil untuk mencegah krisis, melalui manajemen isu, penghindaran risiko, dan manajemen reputasi. (c) Crisis preparation, seperti mempersiapkan tim yang terampil/cekatan dalam penanganan krisis, memilih juru bicara, dan sebagainya. Kedua, tahap crisis, memiliki dua sub tahap, yaitu: (a) Crisis recognition, pengenalan krisis. Anggota dalam organisasi harus menyadari bahwa ada krisis dan menanggapi peristiwa yang terjadi diterima/dilabeli sebagai krisis. (b) Crisis containment. Manajemen puncak segera bertindak pada saat krisis terjadi, membuat sebuah pusat informasi sebagai representasi perusahaan yang dilengkapi dengan berbagai peralatan elektronik komunikasi, menceritakan suatu kejadian secara menyeluruh, terbuka, dan jujur. Jika memang ada yang salah, segera mohon maaf. Serta menunjukan keseriusan organisasi atau lembaga, bukan saja dalam pernyataan tetapi juga dalam tindakan nyata (Singh, 2014). Ketiga, tahap postcrisis. Beberapa tindakan pasca krisis antara lain: mengevaluasi manajemen krisis, belajar dari krisis, dan menindaklanjuti komunikasi dengan para pemangku kepentingan, serta terus memonitor isu-isu yang berkaitan dengan krisis.

\section{Metode Penelitian}

Penelitian ini adalah penelitian kualitatif dengan pendekatan fenomenologi. Sebagai penelitian kualitatif, penelitian ini mencoba memaknai lebih dalam makna yang oleh sejumlah individu atau sekelompok orang dianggap berasal dari masalah sosial, kemanusiaan dan tentu lingkungan. (Cresswell, 2013). Penelitian kualitatif sangat cocok untuk digunakan dalam penelitian tentang kepemimpinan perepmpuan dalam penanggulangan Covid-19 karena bisa menggali fenomena yang ada dengan sangat mendalam dan detail sehingga memudahkan peneliti dalam menjawab pertanyaan penelitian.

Pengumpulan data dilakukan dengan melakukan wawancara mendalam kepada para informan, observasi ke lapangan, dan studi dokumentasi. Pengumpulan data berupa wawancara dan observasi yang akan dilakukan adalah tetap dengan memperhatikan protocol lesehatan dari kementerian kesehatan Republik Indonesia agar memperhatikan keselamatan peneliti pada saat melaksanakan penelitian lapangan. Data dalam penelitian ini bersumber dari data primer dan sekunder. Data sekunder diperoleh 
dari studi literature berupa jurnal-jurnal maupun bahan bacaan yang bisa diakses melalui online.

Validasi data dengan cara melakukan triangulasi dari data-data dengan sumber yang berbeda serta bukti-bukti lain yang diperlukan untuk membangun justifikasi tematema secara koheren (Creswell, 2017:283).

\section{Hasil dan Diskusi}

\section{Kebijakan Pembentukan Satuan Gugus Tugas}

Penaggulangan dalam penyebaran virus corona memebutuhkan peran dan keterampilan seorang pemimpin. Karakteristik dan peran pemimpin sangat diperlukan dalam menangani permasalahan pandemi ini sejalan dengan Surat Edaran Mendagri No.440/2622/SJ Tanggal 29 Maret 2020 yang isinya memberikan mandat kepada kepala daerah untuk menjadi Gugus Tugas di daerah. Krisis ini seakan menjadi ujian dan ukuran bagaimana seorang pemimpin mampu menyelesaikan permsalahan pada saat krisis.

Bupati serang langsung menindaklanjuti Surat Edaran Mendagri No.440/2622/SJ Tanggal 29 Maret 2020 dengan Membentuk gugus tugas untuk memudahkan kerjasama dan sinergi dengan berbagai pihak. Pada tanggal 31 Maret 2020, Bupati Tatu langsung menggelar rapat koordinasi dengan seluruh stakeholder terkait diantaranya Kapolres Serang AKBP Mariyono, Kapolres Serang Kota AKBP Edhi Cahyono, Kabag Ops Polres Cilegon Kompol Kamarul Wahyudi, Dandim 0602/Serang Kolonel Inf Mudjiharto, Ketua DPRD Bahrul Ulum, dan Wakil Bupati Serang Pandji Tirtayasa. Agenda yang dibahas dalam rapat ini adalah hal-hal strategis yang harus dilakukan bersama untuk mencegah penyebaran wabah virus.

Seiring dengan perjalanan Satuan Gugus Tugas dalam penanggulangan virus corona, beberapa hal yang dihasilkan adalah adanya kinerja penanggulangan yang massif dilakukan dengan contoh nyata adalah koordinasi yang jelas dan terarah sampai kepada tingkat RT/RW di Desa-Desa di Kabupaten Serang dan aktivitas yang dilakukan untuk pencegahan virus seperti penyemprotan disinfektan dan kampanye menyeluruh kepada masyarakat terkait bahaya dan cara menghindari virus corona.

Satgas percepatan penanggulangan Covid-19 juga menginisiasi terbentuknya Desa Siaga yang tujuannya adalah membentuk Desa yang mandiri dalam melindungi warganya supaya tidak terpapar virus Corona. Desa menjadi wilayah yang harus selalu mendapatkan edukasi karena pemahaman dan kesadaran di masyarakat Desa kadang belum kuat terbangun dalam menangani virus corona ini, maka perlu ada upaya yang massif dilakukan untuk memberikan sosialisasi dan pemahaman yang cukup kepada warga Desa agar mau ikut serta mensukseksan pencegahan virus corona karena ini semua adalah upaya melindungi masyarakat dari semakin merebaknya virus ini.

Bupati Serang juga setelah membentuk Gugus tugas percepatan penanggulangan Covid-19 kemudian membentuk crisis center daerah kabupaten serang/ dengan nomor telepon (0254) 200135 atau 299636. Krisis center ini digunakan untuk menerima aduan atau kabar yang berkaitan dengan Covid-19 agar terus bisa mendapatkan informasi yang valid sehingga upaya penangannya bisa dilakukan dengan sangat cepat dan efektif.

Bupati Serang selaku Ketua Gugus Tugas selalu memantau setiap proses pelaksanaannya agar selalu termonitor. Juga mempererat sinergitas dengan satgas untuk membentuk jejaring koordinasi yang baik dan efektif dalam upaya penanggulangan virus corona. Peran aktif dari Bupati Serang ini memastikan agar segala koordinasi 
berjalan dengan baik dan pelaksanaanya sesuai dengan apa yang diharapkan oleh organisasi dalam hal ini adalah terlaksananya penanganan Covid-19 yang lebih baik lagi. Komunikasi yang dibangun oleh Bupati Serang kepada masyarakat dalam memberikan informasi dan sosialisasi harus valid dan cepat apabila ada informasi yang harus segera disampaikan kepada masyarakat.

\section{Kebijakan Refocusing Anggaran}

Permasalahan anggaran memang menjadi isu yang strategis dalam penanggulangan Covid-19, karena bagaimanapun anggaran adalah sumber daya yang penting dalam memperkuat kebijakan-kebijakan yang akan dikeluarkan oleh pemerintah daerah dalam menaggulangi penyebaran virus corona ini.

Dalam masalah anggaran, Presiden Joko Widodo mengeluarkan Instruksi Presiden Nomor 4 Tahun 2020 Tentang Refocusing kegiatan, Realokasi anggaran serta Pengadaan Barang dan Jasa dalam rangka percepatan penanggulangan virus corona. Inpres ini akan menjadi dasar hukum bagi seluruh kepala daerah dalam melakukan refocusing anggaran yang akan dipergunakan dalam upaya penanganan Covid-19.

Pemerintah Daerah tentu harus cepat tanggap dalam menangani penyebaran virus corona, upaya penanganan ini tentu memerlukan anggaran yang besar. Kepala Daerah dituntut untuk melakukan refocusing anggaran agar upaya percepatan penanggulangan virus corona segera dapat dilaksanakan dengan maksimal. Pemerintah daerah tentu memiliki keterbatasan dalam anggaran apalagi pada daerah-daerah yang pendapatan asli daerahnya masih rendah. Maka dari itu, setiap Kepala Daerah harus mempertimbangkan banyak hal termasuk pengalihan dan pergeseran program yang anggarannya akan dilimpahkan pada penanggulangan Covid-19.

Upaya refocusing atau penyisiran anggaran dalam penanggulangan penyebaran virus corona telah dilakukan sebanyak dua kali oleh Pemerintah Kabupaten (Pemkab) Serang. Penyisiran dan pergeseran anggaran dilakukan pada kegiatan yang bisa ditunda atau dibatalkan, lalu kegiatan yang non prioritas seperti belanja barang atau jasa yang tidak begitu mendesak.

Pada refocusing anggaran yang pertama dilakukan, dari berbagai organisasi perangkat daerah (OPD), didapat anggaran Rp 15 miliar dan dana tidak terduga (TT) Rp 1,5 miliar. Sehingga total dana yang bisa dialokasikan $\mathrm{Rp} 16,15$ miliar, dari hasil refocusing dan dana TT. Refocusing anggaran yang pertama ini untuk estimasi kebutuhan selama 3 bulan. Refocusing anggaran yang pertama sebesar 16,5 miliar ini sebetulnya belum cukup memenuhi kebutuhan penanganan COVID-19 karena hasil rapat Gugus Tugas Percepatan Penanganan COVID-19 Kabupaten Serang, setidaknya dibutuhkan minimal Rp 58 miliar.

Penggunaan anggaran hasil refocusing diutamakan untuk mendukung peningkatan pelayanan di semua fasilitas kesehatan, mulai dari puskesmas hingga rumah sakit. Anggaran itu akan dialokasikan antara lain untuk kebutuhan alat pelindung diri (APD), alat rapid test, hingga obat-obatan. Khusus tenaga medis tentu menjadi prioritas dalam pengelokasian rapid test karena sebagai garda terdepan dalam menanganni pasien-pasien yang terpapar virus corona namun dalam penggunaannya tetap harus memperhatikan prinsip efektivitas dan efisiensi.

Dalam pengadaan alat rapid test, Kabupaten Serang telah mendapat bantuan 1.260 rapid test dari pemerintah pusat, dan dari hasil refocusing anggaran ini pengadaan rapid test berjumlah 2.000. Adapun dalam pendistriusiannya diberikan kepada 31 puskesmas, 119 public safety centre, labkesda, dan Rumah Sakit dr Drajat Prawiranegara 
(RSDP)sebagai rumah sakit yang ditunjuk sebagai rumah sakit rujukan untuk penanggulangan Covid-19 dan rumah sakit swasta di Kabupaten Serang.

Lalu dilakukan kembali refocusing anggaran yang kedua oleh Pemeritnah Kabupaten Serang dengan semula 16,5 miliar rupiah meningkat menjadi 45 miliar rupiah. Refocusing anggaran yang kedua memang perlu dilakukan karena pada rapat satuan gugus tugas memang menyatakan anggaran 16,5 miliar ini masih terlampau kurang untuk menanggulangi penyebaran virus corona.

Sebagai seorang pemimpin di daerahnya, Bupati Tatu sangat menyadari keterbatasan anggaran yang dimiliki oleh daerahnya. Untuk mengatasi keterbatasan anggaran yang dimiliki oleh Kabupaten Serang, Bupati Tatu mendorong terselenggaranya Desa Mandiri dengan kembali membangkitkan jiwa gotong-royong dan kekeluargaan pada masyarakat Kabupaten Serang.

\section{Kebijakan-Kebijakan dalam Penanggulangan Covid-19}

Pada bidang pendidikan, Bupati Serang mengalihkan pembelajaran satuan pendidikan mulai dari PAUD, SD, SMP, serta pendidikan nonformal baik negeri maupun swasta. Pembelajaran yang semula dilakukan di lingkungan sekolah menjadi dilaksanakan di rumah.

Seperti kita ketahui bahwa kondisi penyebaran virus corona masih belum bisa dikendalikan, bahkan masih sangat berpotensi menciptakan klaster-klaster baru dalam penyebarannya. Salah satu klaster yang harus dicegah adalah klaster dari anak sekolah. Klaster anak sekolah sangat mungkin tercipta apabila proses pembelajaran sekolah masih dilaksanakan dengan tatap muka atau secara langsung diselenggarakan di sekolah.

Klaster sekolah menjadi potensi yang harus diredam karena bisa menyebar dari, melalui, dan kepada anak sekolah. Usia anak-anak masih belum bisa menjaga dirinya sendiri dengan baik, belum begitu memahami bahaya virus, dan belum bisa memahami upaya melindungi diri dari tersebarnya virus, terlebih pada anak-anak yang masih bersekolah pada PAUD dan Sekolah Dasar. Belum lagi resiko dari tenaga pengajar dan tat usaha yang mungkin dating ke sekolah dengan menggunakan transportasi umum yang tidak menerapkan protocol kesehatan, akan sangat berpotensi membawa virus dan menyebarkannya pada klaster sekolah. Untuk itu sangat perlu bagi kepala daerah mengeluarkan sebuah kebijakan yang pas dan relevan dalam menyikapi permasalahan pembelajaran sekolah.

Di Kabupaten Serang, pada bidang pendidikan, Bupati Serang mengalihkan pembelajaran satuan pendidikan mulai dari PAUD, SD, SMP, serta pendidikan nonformal baik negeri maupun swasta. Pembelajaran yang semula dilakukan di lingkungan sekolah menjadi dilaksanakan di rumah. Bupati Serang meliburkan sekolah dimulai pada tanggal 16 Maret sampai dengan 28 Maret 2020. Peliburan selama 14 hari ini merupakan langkah awal dalam menahan laju penyebaran virus corona pada klaster anak sekolah.

Untuk memastikan pelaksanaan kebijakan peliburan anak sekolah ini berlangsung efektif dan tanpa pelanggaran dari warga dan siswa, Bupati Tatu, melalui surat Bupati Serang memerintahkan kepada Satuan Polisi Pamong Praja (Satpol PP) untuk siaga dan berja di tempat-tempat wisata dan tempat lain yang berpotensi menghadirkan kerumunan dan orang banyak.

Pelibatan Satpol PP ini untuk memastikan siswa yang libur tetap dirumah karena juga terjadi di beberapa daerah lain, peliburan siswa sekolah malah dijadikan momen untuk berlibur. Beberapa tempat wisata yang ramai setelah peliburan adalah wisata 
pantai, wisata kolam renang, dan pusat perbelanjaan yang perlu dijaga karena malah makin banyak pengunjung setelah diliburkannya sekolah.

Setelah melihat perkembangan dan situasi dalam penyebaran virus corona, Bupati Serang melalui Kepala Dinas Pendidikan mengeluarkan kebijakan untuk memperpanjang kebijakan libur sekolah dan pembelajara dari rumah sampai dengan tanggal 20 Mei 2020. Hal ini tertuang dalam Surat Edaran (SE) Kepala Dinas Pendidikan dan Kebudayaan Kabupaten Serang Nomor: 420/465-Disdikbud, tertanggal 26 Maret 2020. Surat Edaran ini ditunjukan kepada pengawas dan pemilik satuan pendidikan, serta Kepala PAUD/TK, SD, SMP, dan satuan pendidikan non formal. Beberapa hal lain yang diatur dalam Surat Edaran tersebut adalah tentang pelaksanaan Ujian Nasional (UN) yang dibatalkan karena berpotensi tersebarnya virus dari yang terpapar dalam penyelenggaraannya.

Kebijakan yang dikeluarkan ini adalah bentuk ketegasan dari pemimpin dalam upaya penanggulangan penyebaran virus corona. Bupati sebagai pemimpin menggunakan kuasanya untuk kepentingan yang lebih tama yaitu melindungi masyarakat dari bahaya terpapar oleh virus corona. Hal ini menunjukan pemimpin perempuan juga mampu mengambil keputusan secara cepat dan tegas dalam pelaksanaannya.

\section{Kebijakan Bidang Kesehatan}

Bidang Kesehatan merupakan bidang yang sangat perlu diperhatikan karena sebagai garda terdepan dalam penanganan virus corona. Pada bidang kesehatan, Pemerintah Kabupaten Serang menyediakan rumah sakit rujukan untuk pasien suspect corona. Rumah sakit yang ditunjuk adalah Rumah Sakit Drajat Prawira karena dinilai paling representatif dalam menangani setiap kasus covid-19 yang muncul.

Beberapa infrastruktur penunjang dalam bidang kesehatan terus diperbaiki oleh Pemerintah Kabupaten Serang. Hasil refocusing anggaran yang telah dilakukan oleh pemerintah Kabupaten Serang dipergunakan untuk bidang kesehatan diantaranya pengadaan rapid test, pendistribusian Alat Pelindung Diri (APD), dan pengadaan peralatan yang menunjang percepatan penanganan virus corona.pendistribusiannya diberikan kepada Rumah Sakit Drajat Prawira, seluruh puskesmas, dan rumah sakit swasta yang ada di Kabupaten Serang.

Sebagai Garda terdepan dalam menangani ksus positif, para tenaga kesehatan yang setelah dilakukan rapid dan swab test lalu dinyatakan positif terpapar virus corona, maka langsung diberikan istirahat untuk isolasi mandiri dirumah bila tanpa gejala, dan dilakukan perawatan lebih lanjut bila positif dengan gejala yang perlu segera diberikan pengobatan. Tenaga Kesehatan memang sangat rentan dalam terjangkit virus ini karena mereka setiap hari setiap waktu bekerja dan selalu berhubungan dengan para pasien yang mungkin saja sudah ada virus didalamnya. Tenaga Kesehatan juga rentan terhadap daya tahan tubuh yang menurun karena dehidras sebab pada saat bekerja dengan menggunakan APD, mereka harus optimal dalam menangani pasien sehingga kadang lupa akan kesehatannya sendiri.

Perhatian terhadap tenaga kesehatan sangat dibututhkan, dan rapid lalu swab test harus secara berkala dilakukan kepada mereka untuk menghindari penyebaran virus yang cepat karena salah satu dari tenaga kesehatan terpapar dan tanpa gejala. Kepada Tenaga Kesehatan ini, Bupati Serang memberikan apresiasi yang setinggi-tingginya.

Pemerintah Kabupaten Serang juga melalui Dinas Kesehatan melakukan pemantauan dan pengawasan yang sangat intensif terutama kepada warga masyarakat 
yang berstatus orang dalam pemantauan (ODP). Semua hal ini dilakukan guna menekan angka penyebaran virus corona yang masih belum bisa dikendalikan sampai dengan saat ini.

\section{Kebijakan Bidang Pemerintahan}

Pada bidang pemerintahan, Pemkab Serang tetap melaksanakan pelayanan seperti hari biasa. Pemkab memberikan izin terhadap aparatur sipil negara atau ASN yang mengalami sakit untuk dapat beristirahat dan melakukan penyembuhan di fasilitas kesehatan. Dan secara bergantian menentukan pegawai yang masuk kerja atau Work from Home agar tidak terlalu banyak orang dalam kantor tersebut karena beresiko terjadi keramaian dan penyeberan virus akan semakin mudah. Kebijakan lain yang mendukung penanggulangan penyebaran virus corona adalah membatasi jumlah pelayanan yang harus dating langsung ke kantor pemerintah dan menggantinya dengan pelayanan yang diselenggarkaan secara daring.

Beberapa pelayanan dilakukan dengan system online seperti misalnya pelayanan pada Dinas Kependudukan dan Pencatatan Sipil Kabupaten Serang. Disdukcapil telah melaksanakan pelayanan pengurusan dokumen dengan melalui pesan whatsapp. Sepanjang masih merebaknya pandemi Covid-19, maka seluruh pelayanan administrasi kependudukan di Kabupaten Serang dilakukan daring. Pelayanan dengan menggunakan aplikasi whatsapp ini sudah dilakukan dari bulan Maret setelah dinyatakan kasus pertama virus corona di Indonesia.

Sudah sangat banyak masyarakat yang memanfaatkan layanan daring berbasis aplikasi Whatsapp ini untuk mengurus pelayanan administrasi kependudukan. Pelayanan seperti ini lebih efektif dan efisien karena masyarakat tidak perlu lagi dating langsung ke Kantor Dinas Kependudukan dan Catatan Sipil Kabupaten Serang. Kebijakan ini juga mendukung upaya pemerintah daerah Kabupaten Serang dalam penangguangan penyebaran virus corona yang masih belum bisa dikendalikan sampai dengan saat ini. Hal ini karena beraihnya ke system pelayanan daring mampu mebuat masyarakat Kabupaten Serang tetap berada dirumah, mengajukan permohonan dari rumah, dilayani dari rumah, sehingga tidak menimbulakn aktivitas pelayanan yang berpotensi mengumpulkan banyak orang.

Pemerintah Kabupaten Serang memang membatasi pelayanan terhadap masyarakat di masa pandemic, tetapi bukan berarti pelayanan harus berhenti, maka model palayanan daring inilah yang tepat dilaksanakan paa saat ini untuk meredam penyebaran covid-19. Rata-rata masyarakat tersebut meminta untuk membuat surat pindah/kedatangan warga negara Indonesia antar provinsi maupun kabupaten/kota. Permohonan tersebut langsung diproses oleh petugas Disdukcapil Kabupaten Serang.

Setelah dokumen tersebut jadi, warga dapat mengambil langsung ke kantor atau dapat dikirim kembali melalui pesan WhatsApp tersebut. Pengambilan dokumen secara langsung ke kantor Disdukcapil Kabupaten Serang harus selalu memperhatikan protocol kesehatan agar tidak membahayakan masyarakat lain maupun petugas yang melayani. Agar pelayanan daring ini bisa diketahui dan diakses oleh seluruh masyarakat, Pemkab Serang sudah mengedarkan nomor-nomor WhatsApp-nya ke seluruh 17 UPT di Kabupaten Serang.

Kebijakan lain adalah menghentikan kegiatan ke luar daerah seperti studi banding maupun koordinasi yang akan menggunakan anggaran yang lebih dan berpotensi kembali ke Kabupaten Serang dengan membawa virus dari daerah lain apalagi yang 
Volume 2 Issue 3, December 2020

http://hk-publishing.id/ijd-demos

sudah dinyatakan menjadi zona merah karena telah terkonfirmasi banyak kasus positif corona disana.

\section{Kesimpulan}

Kepemimpinan Perempuan yang melekat pada Bupati Serang, Ibu Ratu Tatu Chasanah dalam menanggulangi masa krisis Covid-19 bisa dikatakan cukup menonjol dengan merujuk pada sikap dan kebijakan yang telah dikeluarkan dan dijalankan di masa krisis pandemic ini. Kebijakan yang cepat dan komunikasi yang dibangun kepada masyarakat mencerminkan kepedulian yang menjadi kekuatan utama pada diri pemimpin perempuan. Pemimpin perempuan yang dinilai lebih peka, punya tingkat kepedulian yang lebih tinggi, dan insting merawat terlihat dalam ragam kebijakan yang beliau keluarkan dalam menangani krisis Covid-19.

Sementara karakteristik kepemimpinan yang ditunjukan dalam penanganan Covid ini adalah Bupati Tatu terlihat sangat kuat dalam menekankan pelaksanaan kebijakan yang telah ditetapkan. Dalam penelitian ini juga terlihat bagaimana beliau tegas dan bertanggung jawab dalam menjalankan perannya sebagai seorang pemimpin perempuan.

\section{Tentang Penulis}

Bayu Nurrohman adalah Dosen Program Studi Ilmu Pemerintahan. Ketertarikan risetnya pada bidang Kepemimpinan Pemerintahan, pelayanan sector public, dan keuangan pemerintahan.

Gilang Ramadhan adalah Dosen Program Studi Ilmu Pemerintahan. Ketertarikan risetnya pada bidang Statistik, perubahan social, dan sosiologi antropologi.

\section{References}

Coombs. (2007). Ongoing Crisis Communication: Planning, Managing, and Responding. USA: Sage Publications

C.Turney, (1992) Conceptualising the management process) New Jersey: Prentice. Hall Inc

Creswell, John W. 2017. Research Design, Pendekatan Kualitatif, Kuantitatif dan Campuran Edisi 4. Yogyakarta: Pustaka Pelajar.

Danim, Sudarwan. 2004. Motivasi Kepemimpinan \& Efektivitas Kelompok. Jakarta: PT Rineka Cipta

Fadhilah, A. (2011). Struktur dan Pola Kepemimpinan Kyai dalam Pesantren di Jawa. Hunafa: Jurnal Studia Islamika, 8(1), 101-120.

Fearn-Banks, K. 1996. Crisis Communications: A casebook Approach. Mahwah NJ: Lawrence Erlbaum.

Fitriani, Annisa. 2015. Kepemimpinan Perempuan. Jurnal TAPIs Vol.11 No.2. p1-24 
Volume 2 Issue 3, December 2020

http://hk-publishing.id/ijd-demos

Ian I. Mitroff, Paul Shrivastava, Firdaus E. Udwadia. (1987). Efektif Manajemen Krisis (Effective Crisis management). The Academy of Management Executive (1987-1989), Vol. 1, No. 4 (Nov., 1987), pp. 283- 292. United States: Academy of Management

Singh, A. (2014). Challenges and Issues of Generation Z. IOSR Journal of Business and Management. https://doi.org/10.9790/487x-16715963

Thoha, Miftah.2010. Kepemimpinan Dalam Manajemen. Jakarta: PT. Raja. Grafindo Persada

Wieringa, S. (2010). Pasang Surut Gerakan Perempuan Indonesia. Perempuan Dalam Relasi Agama Dan Negara, 26-35. 